Cahiers $d u$ MONDE RUSSE

\section{Cahiers du monde russe}

Russie - Empire russe - Union soviétique et États indépendants

$56 / 4 \mid 2015$

Médiateurs d'empire en Asie centrale (1820-1928)

\title{
Colleen McQuillen, The Modernist Masquerade, Stylizing Life, Literature, and Costumes in Russia
}

\section{Anna Fishzon}

\section{(2)enEdition}

\section{Journals}

Electronic version

URL: http://journals.openedition.org/monderusse/8245

DOI: $10.4000 /$ monderusse. 8245

ISSN: $1777-5388$

\section{Publisher}

Éditions de l'EHESS

\section{Printed version}

Date of publication: 1 October 2015

Number of pages: 824-828

ISBN: 978-2-7132-2507-9

ISSN: $1252-6576$

Electronic reference

Anna Fishzon, «Colleen McQuillen, The Modernist Masquerade, Stylizing Life, Literature, and Costumes in Russia », Cahiers du monde russe [Online], 56/4 | 2015, Online since 01 October 2015, Connection on 24 September 2020. URL : http://journals.openedition.org/monderusse/8245 ; DOI https://doi.org/10.4000/monderusse.8245

This text was automatically generated on 24 September 2020. 


\title{
Colleen McQuillen, The Modernist Masquerade, Stylizing Life, Literature, and Costumes in Russia
}

\author{
Anna Fishzon
}

\section{REFERENCES}

Colleen McQUILLEN, The Modernist Masquerade, Stylizing Life, Literature, and Costumes in Russia, Madison : University of Wisconsin Press (Studies of the Harriman Institute), 2013, xv + $282 \mathrm{p}$.

1 Colleen McQuillen's Modernist Masquerade : Stylizing Life, Literature, and Costume joins a growing body of work on the Russian fin-de-siècle and the Silver Age that is positioned in the interstices of history and literature, contributing to and troubling both disciplines. Cultural histories like Louise McReynolds' Russia at Play: Leisure Activities at the End of the Tsarist Era (2003), Roshanna P. Sylvester's Tales of Old Odessa: Crimes and Civility in a City of Thieves (2005), and Mark D. Steinberg's Petersburg Fin de Siècle (2011) analyze boulevard fiction and the entertainment press to offer insights into everyday meaning-making, collective emotions, and subjectivityephemera and dispersed phenomena commonly avoided by historians. My own Fandom, Authenticity, and Opera : Mad Acts and Letter Scenes in Fin-de-siècle Russia (2013) follows and builds on such interdisciplinary scholarship by addressing the great fin-de-siècle themes of authenticity and sincerity through the melodramatic medium of opera and its celebrity and fan cultures. Similarly, historical studies by literary and theater scholars like Beth Holmgren, Olga Matich, and Catherine A. Schuler expand our understanding of how modernist texts, films, practices, and performances not only reflected self-perceptions of Russian fin-de-siècle audiences, but also introduced and disseminated novel means of self-fashioning. In unique ways most of the abovementioned authors have challenged the boundaries of their home disciplines through utilization of wide-ranging theoretical approaches, sources, and methods ; 
occasionally, they even introduced new forms of academic writing. Although McQuillen does not explicitly set out to engage in radical disciplinary transformation, her aim of showing the early twentieth-century masquerade as literary trope, discourse, performative, and mode of self-expression reveals the perils and rewards of traversing the written and corporeal, visual and haptic. As she moves from literature, feuilletons, advertisements, and memoirs to visual art, fashion, performance, and political theater, McQuillen attempts to connect each to evolving conceptions of selfhood and identity, with varying results.

2 McQuillen's use of masquerade as a frame through which to read late tsarist literature and subjectivity and her explorations of its dual function as plot device and discourse prove especially generative when illuminating the fin-de-siècle preoccupation with artifice and personal authenticity, the public veiling and unveiling of personal truth. As an organized event, the masquerade was a syncretic form, combining the theatricality of the stage with the spontaneity of everyday life; it allowed participants to hide or to play with identity, seen as protean by the turn of the twentieth century. As a literary device it was employed to unmask characters' delusions and moral turpitude-to satirize literary and political opponents or afflict them with madness by proxy. As aesthetic practice in daily life, masquerade entailed not merely costumes and disguise but also cosmetics and modishness, cross-dressing and national identifications. Whether at court, Decadents' private parties, or commercial costume balls, it assisted self-fashioning, statecraft, social politics, and polemics.

Part I of the book, "Imitation and Stylization" is devoted "primarily [to] issues of representation and examines the theoretical problems surrounding parody, imitation, and stylization as discursive strategies in literature and in social performance of personal identity." Part II "Costume Design and Theatricality" investigates "issues of reception and interpretation by treating costume design as a type of legible poetics." (p. 29) Chapters in the first half spotlight the ethics and history of masquerade, specifically, the ways Russian folk and Orthodox Church belief in the consonant "relationship between appearance and essence ramified in the literary representations of masquerade found in Romantic era literature, and later in [Fedor] Dostoevsky's Demons and [Fedor] Sologub's Petty Demon." (p. 39-40) Chapter 2 looks at masquerade as a vehicle of courtly power and explores the coupling of social masking and political agency for terrorist revolutionaries and pretenders to the throne. Chapter 3 investigates constructions and camp subversions of gender identity in the lives and works of Zinaida Gippius and Elizaveta Dmitrieva. Chapters 4 through 7 in the second part of the book discuss the interpenetration of art and life in Symbolist figurative and character costumes, the reconciliation of personal and national history in the "philological masquerade" of Anna Akhmatova, avant-garde épatage, and the nude body in Russian dance.

4 The most stimulating and original chapters illustrate how Decadent and Symbolist literary thematics, discourses, and costumes dovetailed with emerging notions of personhood and gender. For example, "Gender Masquerade : Constructions of Feminine Identity" explores Elizaveta Dmitrieva's ethereal and erotically conflicted fictitious personality and pseudonym Cherubina and Zinaida Gippius's campy, "garish" femme fatale persona (p. 104-105). Borrowing aesthetic elements from female impersonators and dandies, Gippius deployed an excessive femininity (or femininity-as-excess) that exposed and critically commented on the constructedness of gender. Indeed, both 
authors used a mannered feminine discourse, or what psychoanalyst Joan Riviere called "feminine masquerade," to simultaneously disguise and further their masculine-coded ambitions and pursuits, namely, writing and fame. According to McQuillen, the feminine stylizations of Dmitrieva and Gippius indicate a loosening of gender norms; they also, it seems to me, show how melodrama and its paradigm of sexual difference were put in the service of women's authorship and self-creation at the turn of the twentieth century.

5 "Figurative Costumes: Metaphors in Text and Textiles" is another particularly compelling chapter that raises the problem of subjectivity at the fin de siècle via a discussion of literary and actual masquerades, including Artists' Balls organized by the St. Petersburg Academy. Here McQuillen brilliantly draws connections between the increasing conceptuality of the costumes (for example, "Journalism," "Duma" and "Finnish Steam Shipping") and the fluidity, individuation, and communicative potential of emergent public identities. While previously costumes had been donned mainly to impersonate or mask, now they were charged with revealing the wearer's true self and beliefs. McQuillen demonstrates how the sophisticated designs of Artists' Balls were disseminated in simpler forms through fashion magazines and commercial events, prompting broader swaths of the urban population to reflect on the problems and complexities of authenticity and selfhood. The chapter's discussions of Leonid Andreev's play Black Maskers and Alexander Blok's The Fairground Booth (1906) again pursue the era's signature motifs : duplication, authenticity/artifice, and authorship. They would have benefitted, in my view, from sustained extra-literary considerations of the advent and spread of mechanical reproduction and the boulevard press; and from a deeper engagement with the Freudian notion of the uncanny. This is particularly true of the analysis of Andreev's play, in which the Italian Duke Lorenzo hosts a masquerade ball attended by uninvited hybrid monsters and the protagonist's threatening double. The trope of the horrifying, identity-usurping double had particular resonance in late Imperial Russia, as it signaled the collapse of the Law or symbolic authority that typically mediates the inherently hostile and confrontational relationships of semblables.

6 While it is immediately apparent how the masquerade as a heuristic device, much like avant-garde costuming and self-stylizations, effects an estrangement that enables McQuillen and her readers to perceive fin-de-siècle culture and society in new and unusual ways, its capacity to inspire original intratextual readings is less manifest. An early chapter makes the point that "masquerade can operate in literature as a site of exposure: the writer uses anonymity and costumes to spur plot development [and build suspense] while the ensuing scandal unmasks social and individual shortcomings." (p. 47) McQuillen's discussion of Dostoevsky and Sologub confirms this and also stresses that in Demons and The Petty Demon "there is a direct correlation between the physical and spiritual : disguise and distorted appearance symbolize actual or infernal possession." (p.47) While such points are well taken, the focus on masquerade yields largely descriptive readings and contributes less to the critical literature on these novels than one might expect.

7 Similarly, it is difficult to say what the interpretive lens of masquerade adds to the existing scholarship on disguise and carnivalesque rituals as strategies of Russian monarchical rule. Ernest Ziter's Transfigured Kingdom : Sacred Parody and Charismatic Authority at the Court of Peter the Great (2004) masterfully has explained how the 
Comical and All-Drunken Council and other mock church ceremonies upended an apparent sacred order and thereby affirmed Peter I's divine authority. Richard Wortman's two-volume Scenarios of Power : Myth and Ceremony in Russian Monarchy (1995, 2000) already has provided us with an exhaustive account of the ways eighteenth-century monarchs used "foreignness" to legitimate their rule, while tsars in the latter part of the nineteenth century exercised power through displays of nationality.

Despite the early chapters' heavy reliance on the sources and conclusions of others (a common pitfall of interdisciplinarity), McQuillen's book ultimately proffers a fascinating account of the forms and functions of masquerade-one that allows us to see how its themes and symbols transfer from the page to everyday life and realms of structured leisure. The story unfolds as follows : the religious and folk tendency to equate visage and the soul, harmonious beauty and virtue persists despite modernist challenges to ontological certainty and predictability. Though the court ceases by the nineteenth century to rely on carnivaleque inversions of this rhetorical formula to assert its omnipotence and legitimize its power, some modernist fiction continues to deploy the equation of appearance and essence for satirical purposes as well as for the melodramatic effect of exposing evil in the world and in the inner self. At the same time, Symbolists and Decadents split signifiers from signifieds and mock the depth model of identity. They readily exhibit the deceptiveness of ball costumes and everyday dress even as they use both for self-fashioning and cultural politics. The destabilization of selfhood and identity proceeds apace until the Futurists, who flamboyantly disrupt social conventions not, to my mind, because they believe in authenticity less but because they believe in it more than their predecessors. The avant-garde rebels against societal norms because it views them to be inherently false, a façade masking or distorting a subterranean truth-the material for autonomous and ahistorical self construction. The avant-garde's disregard of cultural historicity and contingency is of course what draws its members to the Bolsheviks: both have a penchant for brutal sincerity and for theatrical displays of authenticity, the New Man reborn with every performance. Modernist Masquerade leaves unexamined precisely this performative dimension of authenticity and the omission leads to some provocative albeit underdeveloped and confusing claims in the book's concluding chapter.

In "Conclusion: Early Soviet Masquerade" McQuillen, following Sheila Fitzpatrick, suggests that Soviet citizens were compelled "to engage in some form of imposture so they could fit into the new order"-a theatricality that partially explains the ever-vigilant and anxious postrevolutionary attitude toward impersonation and masks. (p. 206) According to McQuillen, the Bolsheviks' understanding (and, I would stress, disavowal) of the contingency of identity as well as the legacy of religious beliefs linking disguise to demonism led to the their paranoia about ideological betrayal and enemy impostors ; as did pre-1917 modernist experimentations with masquerade. (p. 205-206) The Soviet state's obsession with "tearing off the masks" confirms this for McQuillen. Clearly the author is on to something and masquerade seems a potentially fruitful entry point into early Soviet cultural analysis. But theatricality is not artifice in this case. What McQuillen calls "theatrical" and "paranoid" is, in my view, a melodramatic aesthetic of excess that equated moral virtue with avowal. Bolsheviks' obsession with public exposure and confession-their ecstatic performances of unveiling-relate less to Symbolist paradigms than to avant-garde and turn-of-the-century realist theater, as the author readily admits. No wonder the Soviet 
state never organized masquerade balls. "Tearing off masks" was propelled not by actual postrevolutionary dissembling and failed efforts to play new parts but by a utopian, melodramatically inflected discourse that sought ideological purity, denied metaphor, and demanded perfect legibility.

\section{AUTHORS}

ANNA FISHZON

Duke University 